International Journal of Social Science (IJSS)

Vol.1 Issue.5 February 2022, pp: 617-626

ISSN: 2798-3463 (Printed) | 2798-4079 (Online)

\title{
THE EXISTENCE OF TEJAKULA WAYANG WONG DANCE DRAMA, A CULTURAL HERITAGE FOR PRESERVATION, DELAMINATION, AND TOURISM ATTRACTION
}

\author{
By \\ I Gusti Ngurah Sudibya ${ }^{1}$, Een Herdiani ${ }^{2}$, Endang Caturwati ${ }^{3}$, \\ Sri Rochana $W^{4}$, Suzen HR Lumbuan Tobing ${ }^{5}$, Muhammad Mughni Munggaran ${ }^{6}$ \\ ${ }^{1}$ Dosen Prodi Tari, Faklutas Seni Pertunjukan, ISI Denpasar \\ 2,3Dosen Pascasarjana, ISBI Bandung \\ ${ }^{4}$ Dosen Seni Pertunjukan, ISI Surakarta \\ ${ }^{5}$ Dosen Prodi Film dan Televisi, IKJ \\ ${ }^{6}$ Asisten Dosen Prodi Tari, ISBI Bandung \\ Email: eenherdiani867@gmail.com ${ }^{2}$
}

\begin{tabular}{l}
\hline \hline Article Info \\
\hline Articlehistory: \\
Received Nov 18, 2021 \\
Revised Dec 21, 2021 \\
Accepted Jan 21, 2022
\end{tabular}

Keywords:

Dance Drama,Wayang Wong, Tejakula, Cultural Heritage.
CorrespondingAuthor:

Een Herdiani

Postgraduate lecturer, ISBI Bandung

Email: eenherdiani867@gmail.com

\section{INTRODUCTION}

Wayang Wong is a theatrical dance art performance in which the dancers are human or people instead of puppets at which they all use masks or Tapel. This theatrical art performance elaborates the elements of dance, play, and music into a whole unified work of art. This wholeness can be seen from dance performance itself by combining performance elements such as dance moves, Gending/percussion, vocal chanting, and dialogue and costumes,

\begin{abstract}
The various extent of publications by Tejakula Wayang Wong (literally Human Wayang) indicates the conservation efforts of art observers who jointly maintain this tremendous cultural heritage conforming to their respective capacities.Pengempon residents perform this art performance as sincere and earnest offerings to the Almighty for the abundance of His Blessings. In Bali, there are types of Wayang Wong, e.g., Wayang Wong Parwa and Wayang Wong Ramayana. The Wayang Wong Parwato the play from the epic Mahabharata, while Wayang Wong Ramayana took the play from the epic Ramayana. The emergence of the Wayang Wong dance-drama in Bali is estimated when Balinese artistic life experienced its peak of glory during the reign of Dalem Watu Renggong. It is estimated that artists such as I Dewa Batan from Bunutin Village (Bangli) brought the Parwa dance around the XVII- XVIII centuries, and I Gusti Ngurah Made Jelantik from Blahbatuh Village (Gianyar) brought the Gambuh Dance.These two artists create Wayang Wong's performance art in Tejakula Village. How can this Wayang Wong drama dance still exist and even become a tourism attraction? What are the residents doing to maintain this cultural heritage?These questions become the trigger to find out the answers through interviews, watching live performances, and literature studies to find references as supporting data for this article. Community participation in the owners is the main determining factor for the sustainability of this Wayang Wong dance drama. The district and provincial governments' customs, attention, and motivationtrigger the growth of new awareness for the millennial generation to love their own culture.People's dedication is very high and no doubt because their offerings are not measured financially, but the satisfaction for being able to pray and their own pride because their family witnesses it, children, wives, grandchildren and even very possibly by their own parents. Wayang Wong is regarded as intangible cultural heritage is the correct and precise act to appreciate and motivate its sustainability.
\end{abstract}

Thisisan open accessarticleundertheCC BY-SAlicense.

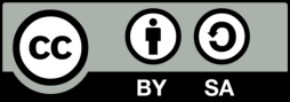


conforming to their respective characters. The story brought up is the epic Ramayana and Mahabarata. Wayang Wong's theatrical art performance applied Mahabharata story is Wayang Wong Parwa, while the Ramayana story is just Wayang WongorWayang Wong by adding the group name or its owner village.The book of Wayang Wong, written by I Made Bandem, also shows the same statements. Two kinds of Wayang Wong are found in Bali: The Wayang Wong Parwa and the Wayang Wong Ramayana. Both take the ancient Hindu epics as their subject matter, which are known and loved in Bali and across Asia. The Wayang Parwa performs stories from the Mahabharata, while the Wayang Wong Ramayana performs stories from the Ramayana (Bandem, 2001:1). In other words, it says two Wayang Wong exist in Bali: Wayang Wong Parwa andWayang Wong Ramayana. Both of them take the epic of ancient Hindu subjects that are popular and beloved in Bali and throughout Asia. Wayang Parwa present Mahabarata tale, while Wayang Wong Ramayana present the tale from Ramayana.

Meanwhile, Soedarsono,in his books, Wayang Wong: The State Ritual Dance Drama In The Court Yogyakarta, in chapter 1, it is written there is strong evidence that wayang (shadow play) and Wayang Wong (dance drama) in Java in the past developed side by side; the former influenced the latter, or in other words Wayang Wong was a personification of Wayang. Thisdevelopment also occurred in Bali and Thailand. Besides wayang Ramayana (shadow from the Ramayana) thereis Wayang Wong (masked dance drama from the Ramayana) in Bali. Besides Wayang Parwa (shadow play from Mahabharata), there is Parwa (dance drama from the Mahabharata) in Bali (Soedarsono, 1990:1). In other words, there is solid evidence that Wayang (shadow puppet) and Wayang Wong (theatrical dance drama) in Java were developed side by side in the past, the first influencing the latter, or in another expression Wayang Wong is the personification of Wayang. This development has also occurred in Bali and Thailand. Besides Wayang Ramayana, there is also Wayang Wong (theatrical mask dance from Ramayana epic in Bali. Besides this Wayang (Wayangfrom Mahabharata), there is also dance drama from Mahabharata in Bali.This statement confirms that Wayang Wong uses the Ramayana and Mahabharata stories. Each one has its uniqueness.

In Bali, Wayang Wong functions as bebalidance because it is performed to complement religious ceremonies. The dance play comes along with religious ceremonies. It is just that the place where the performance is not in the main Mandala but the middle Mandala of the temple area. The other Mandala is located in the outside area called Nistura Mandala.This classification of Wali, Bebali, and Balih-balihan resulted from a seminar on the Sacred and Profan Arts in Dance held by the Bali Cultural Advisory and Development Council (Listibiya) on 24-25 March 1971 in Denpasar(Dibia, 2012:15). This difference can be seen from the context of art sanctity, space, and performance place, time, and the level of the artistic skill of the performer.In addition to the classical character of Wayang Wong's dance drama, because it existed in the past and has a great, noble, and high connotation, it also has instrumental values in living this life. Wayang contains a noble philosophy of life. A Philosophy that contains the nobility of wisdom (Pradana, 2017a), the philosophical teaching reflects human behaviour so that it is effective as information media, education, and entertainment. As stated by Mertosedono (1994), Solichin (2013), and Ruastiti (2020a), Wayang has become a valuable art, elegant art and contains the virtues of life. The story of wayang performances does not merely function as an "entertainment" spectacle but further becomes a guide for the teachings of life, education, and Ngaurip order or "rules of life" (Ruastiti et al., 2020).

The artwork has two aspects: what is visible to the naked eye andtaste (Lango).These two things can be combined to produce a quality work that contains three elements, i.e., truth (Satyam), holiness (Sivam), and beauty (Sundaram).Beauty will appear based on truth, plus the belief that art is God's creation, so holiness becomes a supporting element for the creation of beauty.The Wayang Wong drama dance as an offering is a sacred sacrifice called Yadnya, that art can not only satisfy and fulfill personal or community aesthetic urges but also as a medium for artists to get closer to the source of beauty itself, God who is often said to have qualities of Satyam, Siwam, Sundaram (Dibia, 2003:98).

This Wayang Wong Tejakula drama dance is a noble work of art and a means of ritual, human activities for worship, supplication, and expression of gratitude for the blessings bestowed upon him. This offering realizes Hindu teachings in Bali about Tri Hita Karana, e.g., maintaining a harmonious relationship between humans and nature, humans and others, and between humans and the Creator (God).The local community conveys their devotion by presenting the Wayang Wong dance drama during a series of religious ceremonies (Piodalan) at one of the temples in the Tejakula area. This relation is not just standard or regular, but it is specific or exceptional in natureso that humans make an appropriate way to carry out the meeting, then a ritual appears with all its aspects in the form of symbolic expressions, including artistic expressions, "dance" (Hadi, 2007: 86)

This culture is established from the local culture developed conforming to its own history. These areas' experiences and capabilities provide answers to challenges and the socialization process conforming to their culture and coloring the personalities that emerge in the cultural area (Kayam, 1981:16). This contribution makes Wayang Wong Tejakula can survive with its unique style.According to the author, this peculiarity arises from a simple 
International Journal of Social Science (IJSS)

Vol.1 Issue.5 February 2022, pp: 617-626

ISSN: 2798-3463 (Printed) | 2798-4079 (Online)

motion. Art connoisseurs who attended the performance could see the dance movements clearly according to the characters played. The local culture owned by the Tejakula residents is maintained and has existed until now.

From the description above, the question arises, how can this Wayang Wong dance drama still exist and even become a tourism attraction? What do residents do to maintain this cultural heritage?

\section{DISCUSSION}

It takes a long journey and winding roads starting from Batur village, Kintamani, to Madenan, and finally arrived at Tejakula. These arethe silent witness of the effort to watch the Wayang Wong Tejakula performance live at Dangin Carik Temple, Tejakula Village, Tejakula District, Buleleng Regency, Bali. This performance site is 81.3 kilometers away from the northeast of Denpasarcity. Wayang Wong Tejakula still existed and survives until today. The community fully supports this existence, Regency government of Bali province government.With their beliefs and customs that have become conventions, community members hold fast to mutual respect for the professions in them, unite and synergize to make this cultural art activityan offering and prostrate to the Almighty. The government also has an obligation to maintain and guide while preserving it provides various places to perform as a tourism attraction. One of them is by performing the dance in a grand art event called the Bali Arts Festival (At the Bali Arts Festival in 2021, Sekaa Wayang Wong Guna Murti, Tejakula Village, Tejakula District, Buleleng Regency, performed at Natya Mandala on Thursday, 01 July 2021 at 19.00 by taking the play "Kumbakarna Rumaksa Bhuana).

The brief history of creating Wayang Wong in Tejakula, according to Mr.Ketut Suarna Dwipa,who obtain the information from his predecessorsafter the performance of the Gambuh dance drama at one of the temples in Tejakula village, some people are Kerauhan or trans. The ritual must have an Ilen-Ilen presented aside from Gambuh dance drama (interview, 20 October 2021). A quote from the book in Wayang Wong manual as Balinese Traditional art. It is explained that:

One day, there is a Gambuh performance from the village.After this performance, a "Kerauhan" person said that Ida Bhatara, who resided at the Pemaksan temple and Dangin Carik temple, wanted to have art used to accompany a ceremony at the temple. As a result, the artist gathered various kinds of wood used as a Tapel (mask). The process of collecting the wood takes a long time; everytime they look at the wood, it looks like Hanoman, Rahwana, Sugriwa, Rama Tapel, and others. It finally finished forming the entire characters in Ramayana (Drs. Bagus Nyoman Putra, 1978/1979:1,8,9 in Suarnadwipa, 1986).

Wayang Wong Tapel (mask) is well stored and maintained by Pengempon or the people who dedicate themselves to performing using these masks, and these masks also have a character consisting of two camps. One side is on the Rama faction, and the other is the Rahwana faction. There are four human figure masks, five main giants, 12 main ape masks, 12 ape masks, and nameless giants. Some of the masks werea gift from the Bangli King to the Pasek Dangka clan in the $18^{\text {th }}$ century (Bandem, 2004:87).
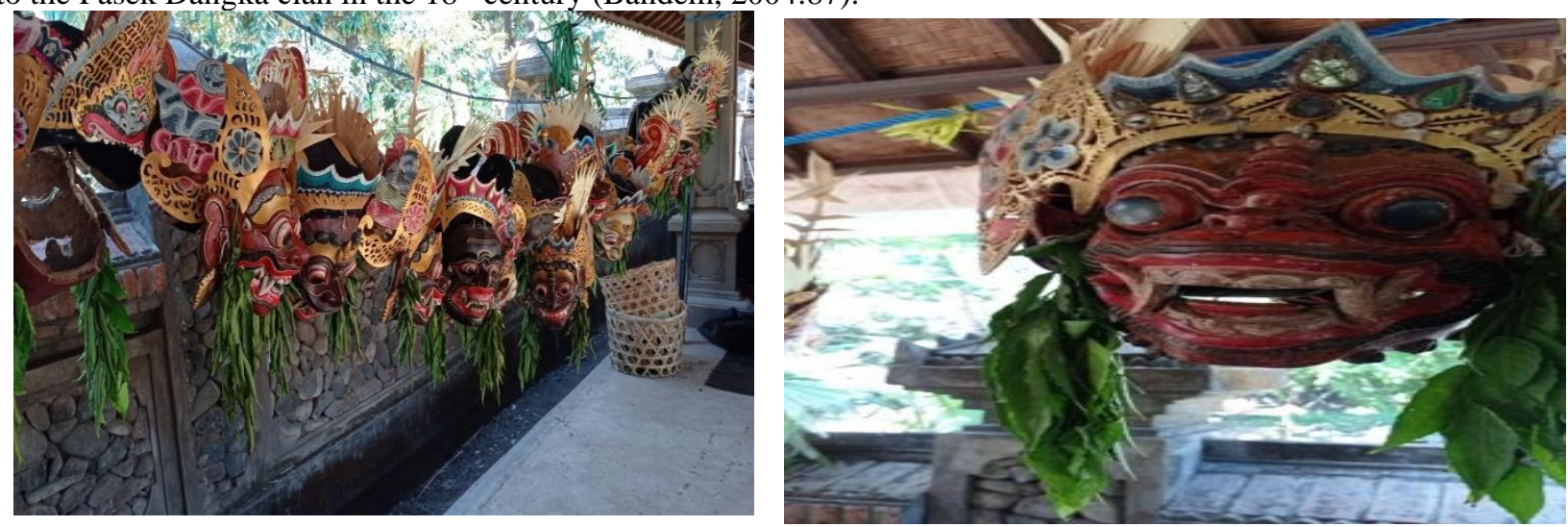

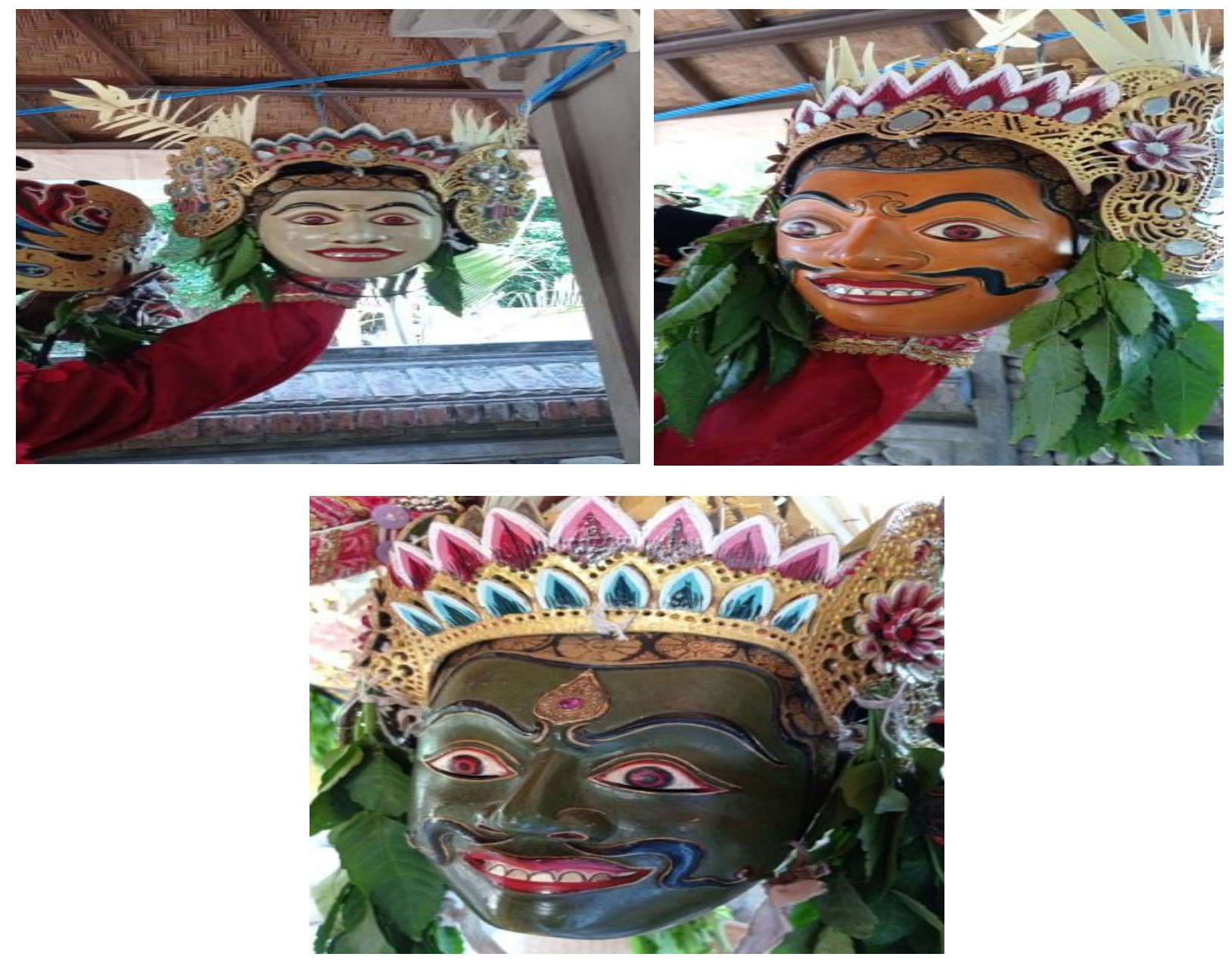

Figure 1. Wayang Wong masks are hung after being decorated to be displayed at the Dangin Carik Temple ceremony on 20 October 2021 at 16.00 - finished.

Documentation by Sudibya, 2021.

There is a concern that this cultural heritage will be about to fade away as written by the researchers in the Journal of Arts \& Humanities, Education Values in Wayang Wong Innovative Arts' Cupu Manik Astagina'The existence of Wayang Wong in Bali today is increasingly marginalized. Only a few places of Wayang Wong performances are found in Bali, namely in North Bali, such as Tejakula Village and Anturan Village, Buleleng Regency. While in South Bali, the art of Wayang Wong'sperformance can be found in the Village of Tadap, Tabanan Regency, in Tonja District of Denpasar, and Tanjung Benoa Village in Badung Regency. For this reason, efforts to rescue local geniuses from ancestral heritage need to be carried out (Ruastiti, 2019). The art of Wayang Wong, which is now threatened with extinction, should be maintained. Local genius Wayang Wong whose educational value requirements for this future generation, should be preserved and developed.(Ruastiti, 2019;92)

In another term:

The response of the Millenials generation on the art innovation of Wayang Wong, the Current Existence of Wayang Wong is increasingly marginalized in Bali. There are only a few places in Bali for Wayang Wong's performance, in North Bali, such as Tejakula Village and Anturan Village, Buleleng Regency. While in South Bali, Wayang Wong art performance can be found in Tadap Village, Tabanan Regency, in Tonja Denpasar Subdistrict, Tanjung Benoa Village in Badung Regency. Therefore, the effort for saving local genius from the ancestor heritage needs to be made (Ruastiti, 2019). Wayang Wong's art performance must be preserved, which is now about to extinct. The local genius of Wayang Wong, which is filled with its educational values for the future generation, must be preserved and expanded.

The above concern might be reasonable, but one of the other proofs in the other research by Abli, Mc. Kean (1973) writes that establishing international tourism did not destroy culture (art); on the contrary, it strengthened the 
International Journal of Social Science (IJSS)

Vol.1 Issue.5 February 2022, pp: 617-626

ISSN: 2798-3463 (Printed) | 2798-4079 (Online)

art ... The tradition of Bali will prosper in direct proportion to the success of the tourist industry. Far from destroying, running, or spoiling the culture of Bali ... the advent of tourist income is likely to fortify and foster the arts' (wood 1979 in Ardika, 2004:3).This cultural heritage needs to be preserved and developed, but the concern for extinction is dismissed by a person who plays the character Delem in this Wayang Wong dance drama. This Wayang Wong drama dance will not be extinct because every ceremony must be staged, such as on the Legi and Pahing day of Galungan. This holy day comes every 210 days.The Wayang Wong show is performed on two days during the Odalan festival and is held at the temple, which coincides with the most important holiday in Bali, Galungan day, every 210 days(Bandem, 2004:88). Not to mention when there are ceremonies at other temples in Tejakula village. For example, the author received information after the performance on 20 and 21October 2021 at Pura Dangin Carik; on 4 and 5November 2021, this Wayang Wong Tejakula will perform again at another temple. The people who attended the performance were very enthusiastic.
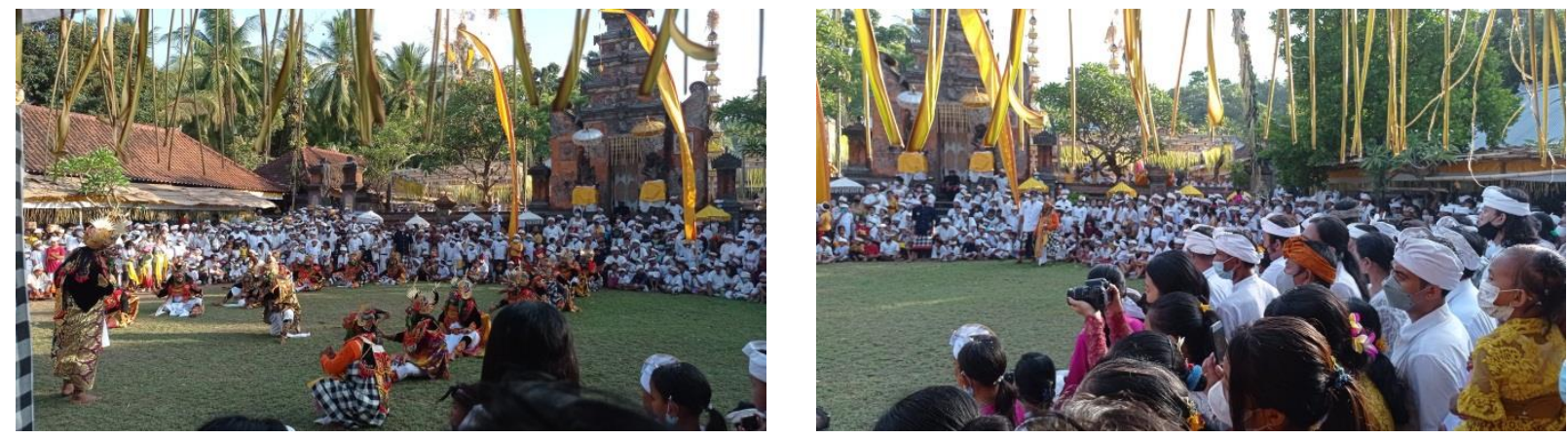

Figure 2.The public enthusiasm to witness

Wayang Wong Tejakula performance on 20 October 2021

Documentation by Sudibya, 2021.

In every performance, this art that uses people as puppet characters by conducting direct dialogues in Kawi language and Alus, Madya, and Lumrah Balinese language (especially in Tejakaula Village) uses two patterns.The first pattern is that the performance only shows stories related to the coronation of Senapati, who will fight from each side (Ravana / Rama). The second pattern is staging the war from each of these camps the next day. In the first pattern on the first day, the atmosphere flows a bit flat, while on the second pattern on the second day, the atmosphere is very dynamic because sometimes the Palawaga (ape) tails in the war scenes carried out sometimes collide and get stuck with each other.This happens not only between two characters but can be three to five dancers. This incident was cheered by the present children to watch the performance. The joy on the audience'sfaces was very evident when the stuck tails could be released with the help of village security officers called Pecalang. (Interview, 10 October 2021).

Watching the performance on 20 October 2021, starting with the Pategak (opening) Gendingpercussion or a set of Batel gamelan consisting of eight Gender Wayangs, one CencengRicik, one Gong unit, two Drum (MaleFemale), one unit Gentorag, one unit Klenang, and one unit Pletuk (Figure 4).Tandak or dialogues that are sung adorn the show duration, which several lines explain the storyline. Then it is followed by the appearance of Tualen and Merdah (clown Rama). 


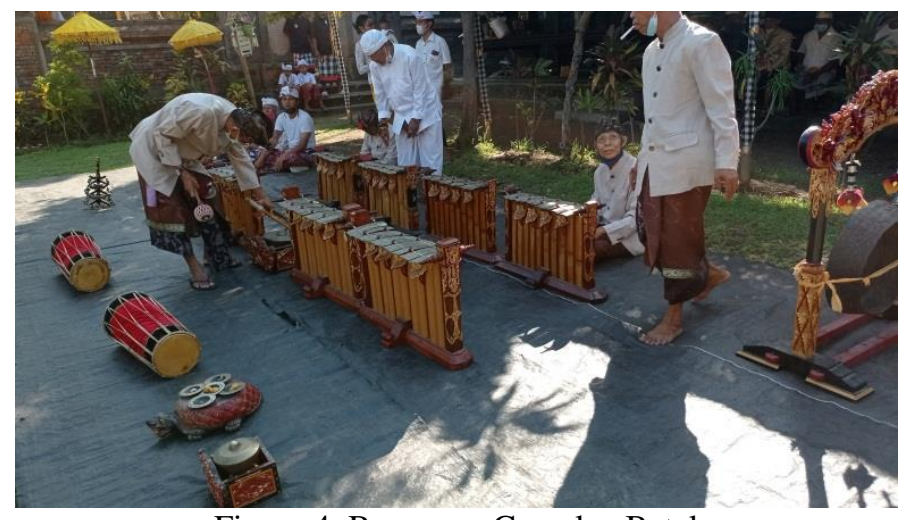

Figure 4. Barungan Gamelan Batel

Documentation by Sudibya, 2021

The following characters who appear are Rama, Laksamana, and Wibisana. Tualen and Merdah meet Sugriwa and the entire monkey army, and they are asked to come before Rama. Rama ordered Sugriwa to prepare senapati to face the enemy from Lengka Pura.The next scene is Delem and Sangut and king Ravana. It is followed by all giants who were also asked to prepare their weapons to fight against the Rama's troop camp.

Rama, Laksamana, Wibisana, Tualen and Merdah, costumes use Sesaputan. Meanwhile, all monkey figures use Awiran. The costumes on Ravana's side are all wearing a sesaputan.
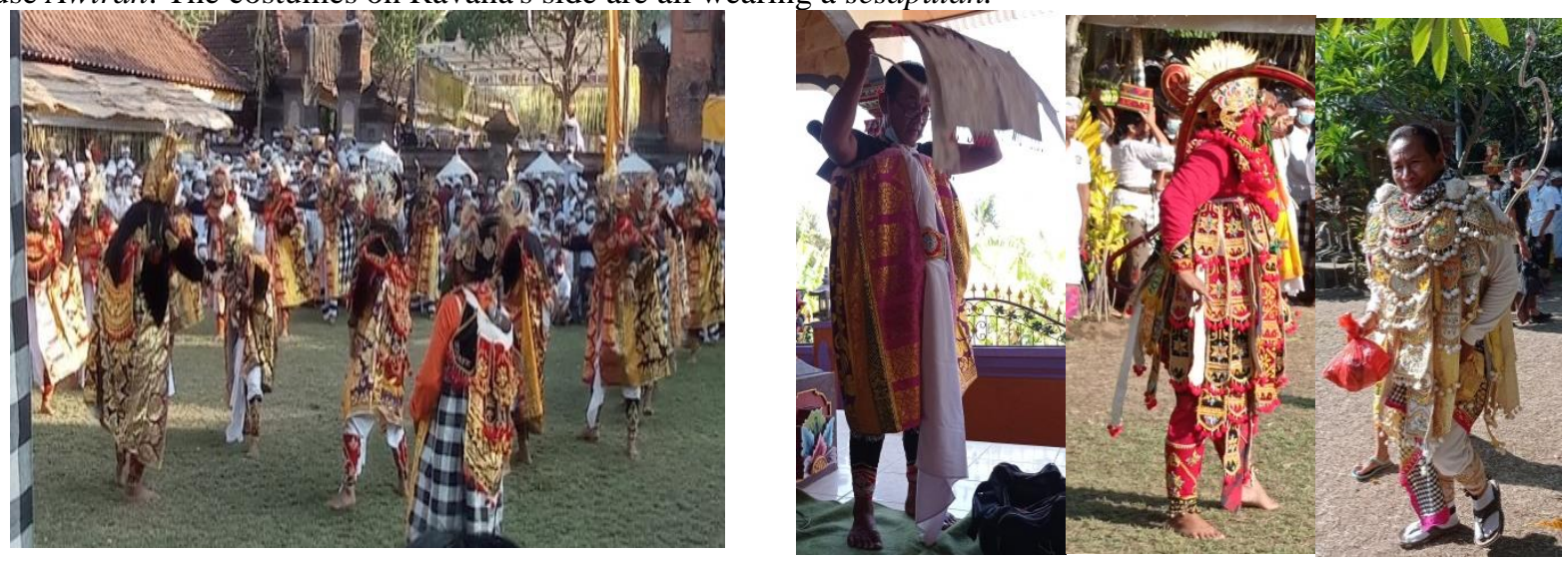

Figure 4. From left to right, Ravana Cs in the Sesaputan costume, he is wearing the Sesaputan costume as the Delem character, the Awiran costume for the Sugriwa and Hanoman characters

Documentation by Sudibya, 2021.

The people involved in the Wayang Wong performance are community members who have married and become Krama (community members/new family members). The membership group can choose, including::

\begin{tabular}{|l|l|l|l|}
\hline 1. & Maksan Kaja & 1. & Pengastulan \\
\hline 2. & Pengastulan & 2. & Maksan Kaja \\
\hline 3. & Maksan Kelod & 3. & Cendek \\
\hline 4. & Baris & 4. & Umbul Kaler/Red and White \\
\hline 5. & Cendek (some sort of Baris) & 5. & Gong Cenik \\
\hline 6. & Gong Gede & 6. & Mamas \\
\hline 7. & Gong Cenik (angklung) & 7. & Pamijian \\
\hline & & 8. & Umbul-umbul Belod \\
\hline & & 9. & Maksan Belod \\
\hline & & 10. & Gong Gede \\
\hline \multicolumn{2}{|l|}{ Informant Source : Ketut Suarna Dwipa(10/10/2021) } & \multicolumn{2}{|l|}{ Informant Source : Gede Widi Adnyana (20/11/2021) } \\
\hline
\end{tabular}


International Journal of Social Science (IJSS)

Vol.1 Issue.5 February 2022, pp: 617-626

ISSN: 2798-3463 (Printed) | 2798-4079 (Online)

Overall, all krama have obligations as Upasaksi (witnesses) in village activities, but under certain conditions, everykrama has a particular task to implement traditional activities or ceremonies in the Tejakula Village area smoothly and successfully. (Interview, 20 November 2021).

As an illustration, an incident ensued, a member who does not continue the line to be Krama (a member of the group above) gets sick, has been taking treatment anywhere, and does not recover. On the advice of the village elders, they were asked to find a shaman, and after receiving instructions, the residents were healthy and resumed their manners. Krama or members of Wayang Wong are about 150 people consisting of dancers, musicians, and Pengayah. Apart from the obligation to become members, they also feel called or obliged and exist based on a vow (interview, 10 October 2021).

The performance on 20 October 2021 at Dangin Carik Temple, Tejakula, was held for the first time after the government imposed PPKM level two due to the Covid-19 pandemic. His Masolah (staged) Wayang Wong Tejakula gave refreshment for art performance inactiveness during the last year.The passion and enthusiasm of the actors and community members who were present at the temple wereevident in their facial expressions. Children, teenagers, adults, parents, photographers, and foreign tourists were also present to watch with great joy. Apart from being preserved, this performance is also a sincere and earnest offering, and at the same time as dissemination that has aesthetic value as a performing art or spectacle and has the value of guidance and order.

The need for tourism requires residents to make duplicate masks, including establishing an association named Guna Murti in 1976 by Mr. Witastra. This mask duplication was made by two local artists, Kompyang Sujana and Gde Sandi. The masks made by Kompyang Sujana are more often used because the size and shape are more fit to the dancers' facial anatomy. Sekaa Wayang Wong performs performances related to religious ceremonies and performs tourism performances and has even made trips abroad, i.e., to Sweden. They also perform domestically, such as Taman Mini, TIM, SKJ, PLN Central Office, Rawamangun Temple, Mandara Giri Semeru Temple, Lumajang, Gerembung - Sidoarjo, Bali Arts Festival, Buleleng Festival, Mask Museum in Kemenuh Gianyar Village, and Ubud Palace perform staging.So related to performances at temples, the masks used are sacred masks, while duplicate masks are used (interview, 10 October 2021). Although tourism performances have developed since the 1930s (Dibia, 2012:151), it does not mean that Wayang Wong Tejakula is too late in anticipating it. This may be a demand for tourism at that time was not needed. The presence of Wayang Wong Tejakula, who is quite old (XVII XVIII centuries), is required to adapt to the present-time dimensions and language and image shifts and new identifications because it is the dimensions and language-time that demand so.

Shadow Puppet still has a significant influence on the dance movements in Wayang Wong, especially their hands' movements (Bandem, 2004: 86). Each move they made follows the character of the mask used. Some movements were created from unexpected things, such as holding a towel when planning the formation of dance movements. This movement was created when, in the past, residents finished bathing in the river; on their way home, they were invited to practice dancing. Without realizing it, the towel hung around the neck is used as a costume with the hand position, as shown in Figure 5. This habit is carried over when dancing, but what is worn is not a towel but a shawl. This scarf is held during practice.

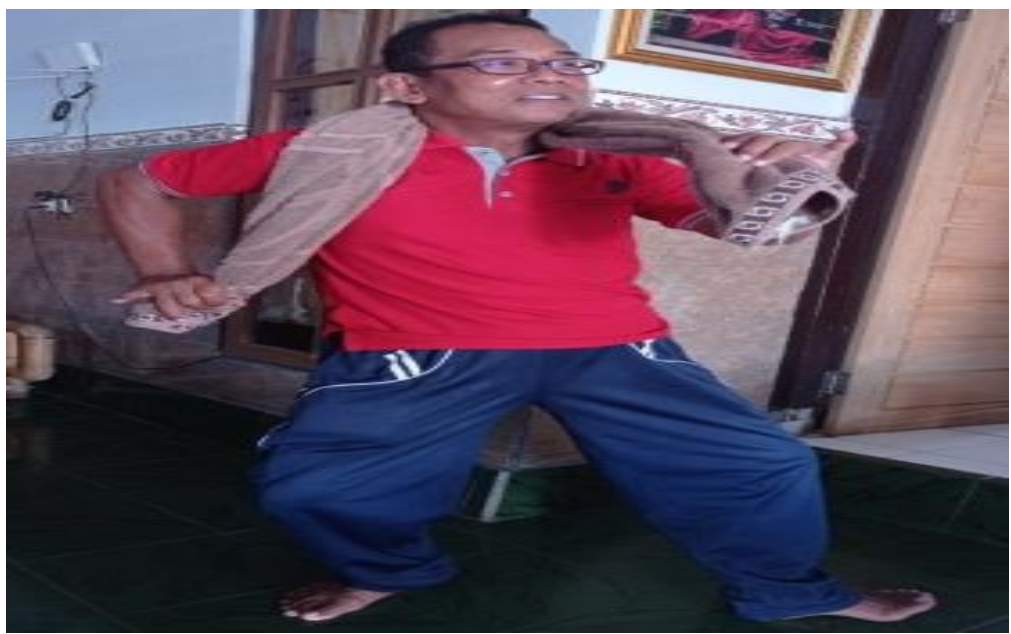

Figure5. one of the movements emerges from the daily activities of the dancers Documentation by I G N Sudibya, 2021 
The place where the Wayang Wong show is performed is in the centralJaba courtyard of the temple. In general, temples have three areas, such asMainMandala (main area/innards), Madya Mandala (central area/central Jaba), and Nistura Mandala (outer region/Jaba side). Central Jabahas a relatively large space, and the area is not in direct contact with religious ritual activities. This area is very appropriate for performances or artistic performances belonging to the Bebali dance (complementary to the ceremony). The dance drama performance is in the afternoon, around 16.00 until it has finished.Apart from avoiding the sun's scorching heat, this timing also allowed the community to pray first and then watch the Wayang Wong show. UNESCO has recognized wayang Wong Tejakula as one of the Intangible Cultural Heritage. and eight others are Rejang, Sanghyang Dedari, Ceremony Row, Legong Palace, Sidakarya Mask, Barong Ket, Gambuh Dramatari, and Joged Bumbung.

\section{CONCLUSION}

The existence of Wayang Wong Tejakula, which is estimated to have been born in the XVII - XVIII centuries, is still well preserved. The performances are not only related to ceremonies but also tourism. Offerings in the form of performances are carried out with complete devotion, sincere and at the same time become an actual preservationeffort.The attendance of the local community watching the Wayang Wong Tejakula performance in the centralJaba of the temple was very enthusiastic.This passion was a kind of resident's appreciation and, at the same time as the contribution of introducing Wayang Wong to the children and younger generation who were present at the temple.

The local village elders' role that helps maintain dance drama sustainability, assisted by the government by providing the stage for certain events both in the district and in the province, is a commendable concern.UNESCO has recognized Wayang Wong dance drama as an intangible cultural heritage. This pride is also all resident responsibility to ensure that its sustainability can be preserved.

Joint research to revitalize Wayang Wong is an excellent step to introduce this culture and develop it corresponding to the needs and progress of the times. However, it also must pay attention to maintaining its roots, nurturing, and preserve, so as not to be uprooted from the earth of our beloved archipelago. Researchers hope that this article can contribute to the sustainability of the prestigious Wayang Wong in the archipelago, especially in Bali.

This research can be carried out with support from the Ministry of Education, Culture, Research, and Technology in a National Priority Flagship program for Higher Education in 2021 Number T/430/IT8.2/PT.01.03/2021.Therefore, we would like to express sincere gratitude to the Director of Resources, Directorate General of Higher Education, Research and Technology, Ministry of Education. Culture, Research, and Technology of the Republic of Indonesia.

\section{REFERENCE}

[1] Ardika, I Gede. 2004. Pengembangan dan Pemberdayaan Kebudayaan Dalam Konteks Kepariwisataan (Mencermati Seni Pertunjukan II, Perspektif Pariwisata, Lingkungan, dan Kajian Seni Pertunjukan; Editor; Santosa), kerjasama Ford Foundation \& Program Pascasarjana STSI Surakarta.

[2] Bandem, I Made. 2001. Wayang Wong, Bali Mangsi Press. Yogya. Akademi Seni Tari Indonesia Denpasar.

[3] Bandem, I Made., Fredrik Eugene deBoer. 2004. Kaja dan Kelod Tarian Bali dalam Transisi, Institut Seni Jogjakarta,

[4] Dibia, I Wayan, 2002. Nilai-nilai Estetika Hindu dalam Kesenian Bali (Estetika Hindu dan Pembangunan Bali; penyunting I B G Yudha Triguna), Program Magister Ilmu Agama dan Kebudayaan UNHI-Widyadarma, Denpasar.

[5] Dibia, I Wayan, 2012. Geliat Seni Pertujukan Bali, Widya Pataka, Bali.

[6] Dibia, I Wayan, 2012. TAKSU Dalam Seni Dan Kehidupan Bali, Bali Mangsi, Denpasar.

[7] Kayam, Umar. 1981. Seni, Tradisi, Masyarakat, Sinar Harapan, Jakarta.

[8] Ruastiti, Ni Made, I Komang Sudirga, I Gede Yudarta, 2019. Education Values in Wayang Wong Innovative Arts 'Cupu Manik Astagina', Journal of Arts \& Humanities, Volume 08, Issue 09, DOI: http://dx.doi.org/10.18533/journal.v8i9.1732.

[9] Ruastiti, Ni Made., I Komang Sudirga, I Gede Yudarta, 2020.The Wayang Wong Millennial Performance Art Model as a New Tourist Attraction in Bali, International Journal of Innovation, Creativity and Change. www.ijicc.net Volume 14, Issue 5, 2020.

[10] Soedarsono, 1990. Wayang Wong, The State Ritual Dance Drama In The Court Of Yogyakarta, Gadjah Mada University Press, Yogyakarta.

[11] Sumandiyo Hadi, Y. 2007. Sosiologi Tari Sebuah Pengenalan Awal, Pustaka, Yogyakarta.

[12] Widyastutieningrum, Sri Rochana. 2018. Reviving Wayang Orang Sriwedari in Surakarta: Tourism-Oriented Performance, Asian Theatre Journal, Vol. 35, No. 1 (spring 2018), by University of Hawaii Press. 